\title{
PEMBUATAN PAPAN LAMINATING DARI TULANGAN BAMBU MENGGUNAKAN LIMBAH PLASTIK SEBAGAI BAHAN PENGISI DAN PEREKAT
}

\section{MAKING OF LAMINATED BOARD FROM BAMBOO USING PLASTIC WASTE AS FILLER AND ADHESIVE}

\author{
Broerie Pojoh \\ Balai Riset dan Standardisasi Industri Manado \\ Jalan Diponegoro No. 21-23 Manado \\ Pos-el :b pojoh@yahoo.com \\ Diterima tgl 28-08-2016, Disetujui tgl 29-09-2016
}

\begin{abstract}
ABSTRAK
Kebutuhan akan bahan bangunan seperti kayu untuk pembuatan rumah panggung sangat besar. Pasokan bahan bangunan untuk mendukung industri rumah panggung tidak dapat sepenuhnya dipasok oleh bahan baku lokal karena semakin menipisnya hutan produksi yang menghasilkan kayu berkualitas baik. Dilain pihak, bambu merupakan tumbuhan lokal yang dimanfaatkan secara luas antara lain sebagai bahan bangunan. Penggunaan bambu untuk menggantikan peran kayu telah mulai dilakukan antara lain dengan membuat papan komposit atau papan laminasi dengan menggunakan bahan perekat seperti PVC. Dilain pihak, plastik digunakan secara masif sebagai bahan kemasan, misalnya untuk botol atau gelas AMDK. Karena kesadaran yang masih rendah maka limbah kemasan plastik banyak berakhir sebagai sampah di badan-badan air. Penggunaan limbah plastik sebagai bahan pengisi dan perekat pada papan laminating tulangan bambu menarik untuk dilakukan. Penelitian dilakukan dengan metode percobaan untuk membuat papan laminating dari beberapa jenis plastik dengan menggunakan bantuan alat cetak sistem panas. Hasil penelitian menunjukkan bahwa jenis plastik PP (ex-gelas AMDK dan tutup botol berwarna) dapat digunakan untuk menghasilkan papan laminating tulangan bambu yang kompak dan keras sekaligus masuk dalam kategori sebagai papan kelas III.
\end{abstract}

Kata kunci: limbah plastik kemasan AMDK, bambu petung, tulangan bambu, papan laminating

\begin{abstract}
Demand for building materials such as wood for the manufacture of a wooden house is very large. Recently, the supply of wood can not be fully supplied by local raw materials due to the depletion of forest production of good quality wood. As an alternative, bamboo is a local plant that is widely used among others as a building material. Research of bamboo to replace wood has begun by making a composite board or laminated board using adhesive materials such as PVC. On the other hand, plastics are being used as a packaging material, eg for bottle or glass of drinking water. Because awareness is still low, the plastic packaging wastes end up as waste in water bodies. Because of that, the use of plastic waste as a filler and adhesive for bamboo laminating boards is interesting to do. This research is carried out through experimental method to make the laminatingboard of several types of plastics with the help of a tool specially made for that. The results showed that the type of plastic PP (ex-glasses of drinking water and colored bottle cap) can be used to produce bamboo laminating boards which is phisically compact and hard and categorized as third class board.
\end{abstract}

Keywords: board laminating, petung bamboo, plastic waste packaging drinking water, reinforcing bamboo

\section{PENDAHULUAN}

Plastik merupakan bahan yang sering digunakan untuk berbagai keperluan, seperti kemasan pada air minum dalam kemasan (AMDK) yang memilikisifatkuat, ringan, fleksibel, dan tahan benturan. Kelemahan utama dari kemasan berbahan dasar plastik adalah ketahanannya terhadap pelapukan yang bisa mencapai ribuan tahun. Oleh karena itu, kemasan plastik yang tidak ditangani dengan baik dan dibuang secara sembarangan biasanya akan berakhir di sungai, danau, dan lautan. Hal ini sudah menjadi isu global yang sangat mendesak untuk ditangani karena telah mempengaruhi siklus kehidupan biota 
laut, terumbu karang, dan estetika laut. Oleh karena itu, upaya pemanfaatan limbah plastik perlu dilakukan untuk meningkatkan pemanfaatannya sekaligus mengurangi pencemaran ke lingkungan. Untuk mengatasai permasalahan lingkungan akibat dari penggunaan plastik maka perlu diupayakan pemanfaatan limbah plastik yang dihasilkan dalam jumlah yang sangat besar. Salah satu alternatif pemanfaatan limbah plastik adalah sebagai matriks di dalam pembuatan papan laminating.

Beberapa jenis plastik yang digunakan secara luas di lapangan adalah PETE or PET(Polyethylene terephthalate), HDPE (High density polyethylene), V or PVC (Polyvinyl chloride), LDPE (Low density polyethylene), PP (Polypropylene), PS (Polystyrene), bahan plastik lainnya. PET atau PP digunakan secara besar-besaran sebagai botol atau gelas AMDK. Kemasan plastik tersebut telah secara masif mencemari badan air di seluruh bagian dunia. Selama ini upaya pengumpulan dan daur ulang telah dilakukan, namun mengalami kendala terkait pengangkutannya karena bahan tersebut bersifat bulky. Penggunaannyakembali sebagai bahan kemasan oleh masyarakat cenderung berisiko karena sifat bahan yang dapat mengeluarkan zat-zat karsinogenik pada kondisi yang ideal untuk itu.

Papan laminating antara lain dapat dibuat dari bahan bambu dengan menggunakan perekat seperti PVC yang diklaim oleh banyak pihak sebagai kayu masa depan. Papan laminating pada prinsipnya bertujuan untuk meningkatkan kekuatan papan yang biasanya berbahan dasar kayu kualitas rendah, seperti sengon dan jambon.

Bambu merupakan tumbuhan penting di Indonesia. Bambu bermanfaat sebagai sumber bahan makanan, tanaman hias, bahan bangunan dan kayu bakar. Di Indonesia terdapat 10 jenis bambu yang digunakan sebagai bahan konstruksi, yaitu Gigantochloa apus (Schult. \&Schult.) Kurz,Gigantochloa verticillata(Munro*), Gigantochloa robusta Kurz, Gigantochloaatter (Hassk.) Kurz,Dendrocalamusasper (Schult.) Backer ex Heyne,Bambusaarundinacea (Retz.) Willd., Bambusa vulgarisSchrad. var. striata,Bambusa blumeanaSchult., Gigantochloa aff. atter ${ }^{*}$ and Bambusapolymorpha Munro)(1). Dunia memiliki 37 juta ha hutan bambu natural ataupun budidaya yang setara dengan satu $\%$ luasan hutan dunia. Dari jumlah itu, lima $\%$ di antaranya terdapat di Indonesia sementara China memiliki 14\%, dan India yang terluas, yaitu 30 persen(2). Jenis bambu yang paling banyak digunakan di Sulawesi Utara sebagai bahan bangunan adalah buluh jawa (Dendrocalamus asper (Schultes f.) Backer exHeyne)dan buluh pagar (Gigantolochloa apus Kurz).

Bambu memiliki sifatmekanik yang menjanjikan. Sebagai struktur bangunan, bambu memiliki beberapa keunggulan dibandingkan kayu. Bambu dua kali lebih kaku dan lebih baik dalam hal kekuatan potong dibandingkan dengan kayu(3).

Penggunaan bambu sebagai papan partikel memberikan hasil yang sangat baik. Plywood dari bambu memiliki kuat lentur 
(modulus of rupture, MOR) dan modulus of elasticity (MOE) tertinggi diantara produkproduk plywood, bahkan sama baiknya dengan kayu keras yang memiliki densitas tinggi(4). Xiao et al meneliti tentang pembuatan bambu laminasi (GluBam) untuk aplikasi pada struktur bangunan. Hasil dari kajian ini adalah produk yang dihasilkan bersifat ramah lingkungan, karena memiliki keunggulan dari sisi sedikitnya energi yang diperlukan untuk produksi dan kurangnya emisi karbon(5). Penggunaannya untuk konstruksi juga sangat menjanjikan. Sudin dan Swamy meneliti tentang pembuatan papan partikel dari bambu sebagai bahan pengisi bersama-sama bahan lainnya yaitu serat kayu dan bahan pengikat semen yang menunjukkan bahwa kombinasi bahan-bahan tersebut menghasilkan papan partikel yang memenuhi standard di Malaysia(6).

Suhasman, dkk meneliti tentang pembuatan papan partisi dari bambu dimana perlakuan yang dilakukan dengan menggunakan perlakuan awal berupa oksidasi menghasilkan papan partisi terbaik dibandingkan dengan papan partisi yang mendapat perlakuan awal dengan menggunakan air mendidih(7). Stabilitas dimensi dan modulus elastisitas dengan perlakuan awal oksidasi juga sangat baik dibandingkan dengan papan partisi konvensional yang menggunakan perekat melamin formaldehida.

Mulana, dkk(8) meneliti tentang pembuatan papan komposit dari plastik daur ulang dan serbuk kayu serta jerami sebagai filler. Hasil penelitian menunjukkan bahwa penggunaan serbuk sebagai bahan pengisi lebih baik dibandingkan dengan penggunaan jerami pada komposisi bahan pengisi 80:20 berturut-turut. Penggunaan serbuk menghasilkan produk dengan kuat tarik 6,86 $\mathrm{MPa}$ yang lebih kuat dibandingkan dengan menggunakan jerami yaitu 3,62 MPa pada komposisi bahan pengisi 60:40 berturut-turut. Suhu tertinggi untuk melelehkan papan komposit adalah $31,19 \mathrm{~J} / \mathrm{g}$ dan $14,02 \mathrm{~J} / \mathrm{g}$ pada rasio komposisi serbuk: limbah plastik 80:20 dan komposisi jerami:limbah plastik 80:20 berturut-turut. Secara visual, papan komposit dengan komposisi serbuk papan:platik HDPE 50:50 kelihatan lebih baik dengan warna terang dan mengkilat.

Kombinasi antara permintaan kayu yang tinggi, umur panen yang lama, dan sistem pemanenan secara total telah berdampak pada kelangkaan bahan baku kayu sehingga mempengaruhi kelangsungan usaha industri kayu dan industri rumah kayu. Salah satu alternatif untuk mengatasi permasalahan tersebut adalah substitusi papan dari kayu dengan papan laminating yang berbahan dasar "tulangan bambu petung" dan limbah plastik yang berlimpah ketersediaannya sebagai matriks/perekat. Penelitian ini dilakukan untuk mengetahui kemungkinan pembuatan papan laminating dari "tulangan bambu petung" dan limbah plastik dengan metode pemanasan.

\section{METODE PENELITIAN}

\section{Metode Penelitian}

1. Desain alat pembuatan bambu laminating 
Pada penelitian ini direkayasa alat pembuatan bambu laminating dengan ukuran $25 \times 20 \times 20 \mathrm{~cm}$. Ruang pemanasan berukuran $25 \times 20 \times 10 \mathrm{~cm}$ dengan sasaran untuk menghasilkan papan laminating yang berukuran $20 \times 15 \times 1,5 \mathrm{~cm} \quad$ (ketebalan tergantung jumlah bahan yang digunakan, yaitu bambu dan limbah plastik). Sumber energi yang digunakan untuk pemanasan adalah gas LPG.

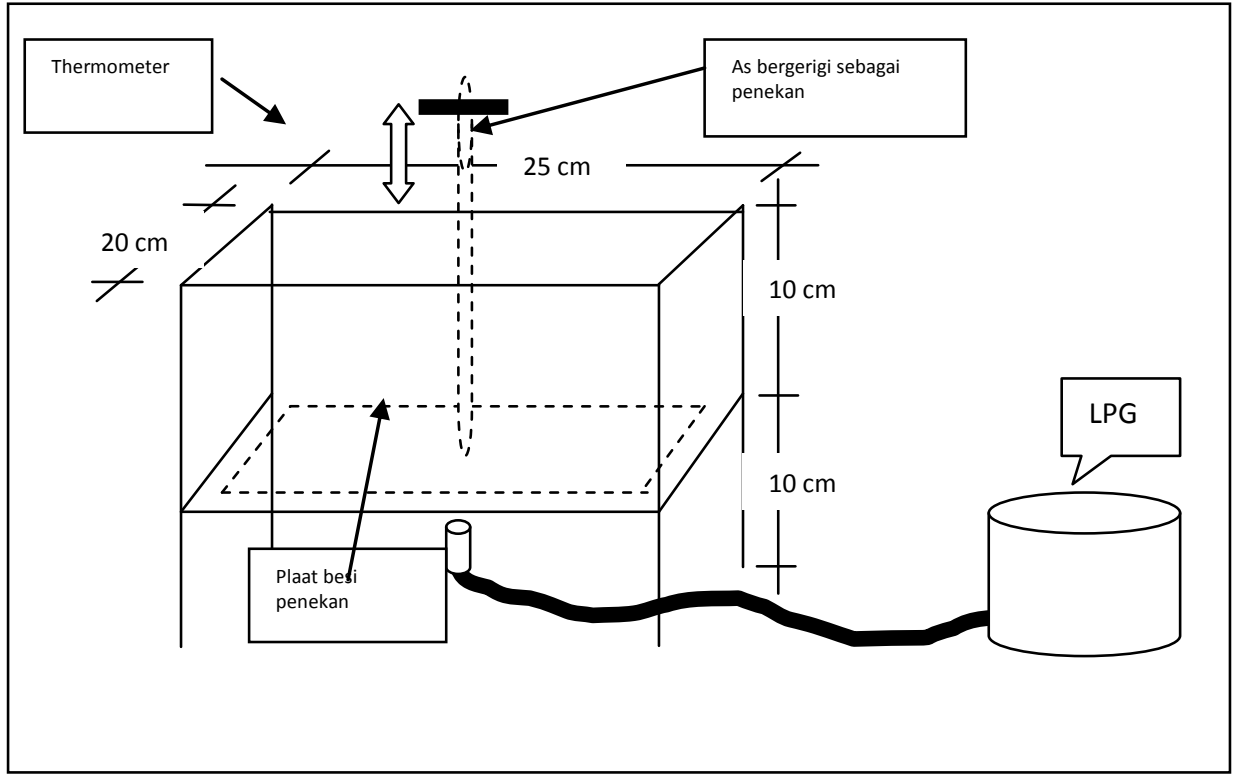

Gambar 1. Sketsa alat cetak papan laminating dari bambu dan limbah plastik

2. Penyusunan bambu

Percobaan dilakukan dengan menggunakan tulangan bambu satu lapis dan tiga lapis yang disusun secara bersilangan. Potongan limbah plastik diletakkan secara merata di bagian dasar, diantara bambu, dan di bagian atas dari tulangan bambu.

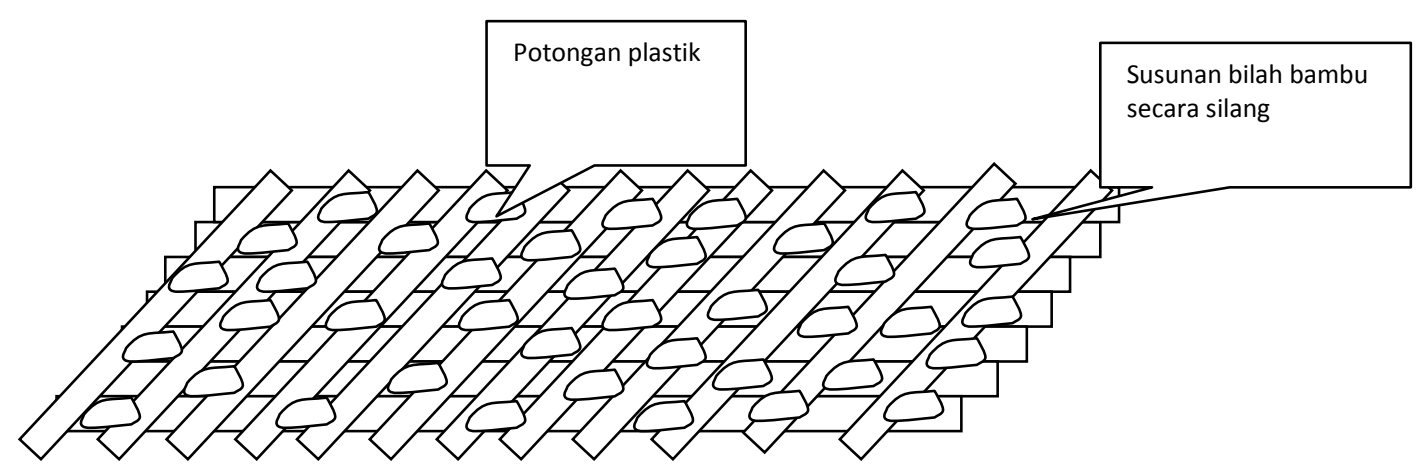

Gambar 2. Susunan bilah bambu dan plastik 
3. Perlakuan penelitian

Tabel 1. Perlakuan penelitian

\begin{tabular}{llll}
\hline No & \multicolumn{1}{c}{ Perlakuan } & Ukuran \\
\hline 1 & $\begin{array}{l}\text { Limbah plastik PET berwarna } \\
\text { kemasan minuman berwarna biru) }\end{array}$ & (bekas & $\pm 5 \times 5 \mathrm{~mm}$ \\
2 & $\begin{array}{l}\text { Limbah plastik PET bening (bekas botol } \\
\text { AMDK) }\end{array}$ & $\pm 5 \times 5 \mathrm{~mm}$ \\
3 & $\begin{array}{l}\text { Limbah plastik PP (bekas gelas AMDK } \\
\text { bening berawan) }\end{array}$ & $\pm 5 \times 5 \mathrm{~mm}$ \\
4 & $\begin{array}{l}\text { Limbah plastik PP (bekas penutup botol } \\
\text { AMDK dan minuman lainnya) }\end{array}$ & $\pm 5 \times 5 \mathrm{~mm}$ \\
\hline
\end{tabular}

Ket: masing-masing diulang tiga kali.

4. Ukuran tulangan bambu

Bagi tulangan bambu yang disusun satu lapis, ukuran tulangan bambu yang digunakan adalah $18,5 \times 1 \times 1 \quad \mathrm{~cm}$. Sedangkan tulangan bambu yang disusun tiga lapis secara bersilangan memiliki ukuran $18,5 \times 0,5 \times 0,5 \mathrm{~cm}$ untuk tulangan sisi panjang dan $1,3 \times 0,5 \times 05 \mathrm{~cm}$ untuk tulangan bambu sisi lebar.

\section{Pengamatan}

Pengamatan terhadap produk papan bambu laminating yang dihasilkan dilakukan secara visual terhadap kompaknya produk yang dihasilkan (dilengkapi dengan foto produk) dan kuat lentur dari papan bambu laminating yang dihasilkan.

6. Prosedur penelitian

1. Limbah plastik dihaluskan dengan ukuran $\pm 5 \mathrm{~mm}$

2. Potong tulangan bambu (yang telah diawetkan) dengan panjang 20 dan 15 $\mathrm{cm}$, lebar $1 \mathrm{~cm}$, tebal $5 \mathrm{~mm}$
3. Letakkan potongan limbah plastik di bagian dasar ruang pemanasan dengan ketebalan sekitar $2 \mathrm{~cm}$.

4. Susun 10 potongan bambu di atas limbah plastik secara sejajar dengan posisi membujur menggunakan bambu ukuran panjang $20 \mathrm{~cm}$. Di atasnya diletakkan potongan limbah plastik setebal $2 \mathrm{~cm}$, kemudian letakkan 15 potongan bambu secara sejajar dengan posisi melintang menggunakan bambu ukuran $15 \mathrm{~cm}$. Di atasnya diletakkan potongan limbah plastik dengan ketebalan yang sama seperti lapisan sebelumnya, kemudian letakan potongan bambu seperti lapisan pertama, dan tutup dengan meletakkan potongan limbah plastik dengan ketebalan yang sama. Limbah plastik kering yang digunakan untuk setiap pembuatan benda coba adalah sebanyak 200 gram.

5. Tutup alat pemanasan dengan cara memutar ulir penutup sehingga susunan potongan bambu dan limbah plastik menjadi padat. 
6. Panaskan alat dengan api sedang.

7. Amati temperatur ruang bakar menggunakan termometer.

8. Pemanasan dilakukan selama \pm 1 jam sampai suhu ruang bakar mencapai $120-140{ }^{\circ} \mathrm{C}$ (sesuai titik lebur plastik).

9. Setelah suhu ruang bakar tercapai maka kompor gas dimatikan.

10.Tunggu suhu ruang bakar turun sampai $80^{\circ} \mathrm{C}$ baru alat dapat dibuka.

\section{BAHAN DAN ALAT}

\section{Bahan}

Bahan yang digunakan adalah bambu petung (buluh taaki), limbah plastik PET, PP, besi plaat, dll.
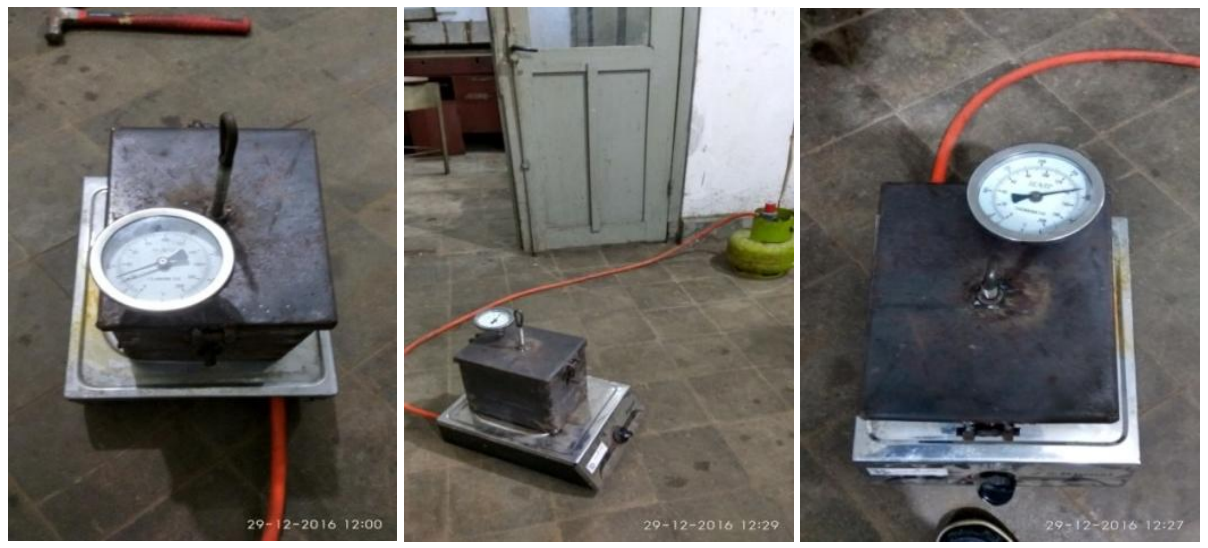

Gambar 3. Foto alat pembuatan papan bambu laminating menggunakan limbah plastik

Pada percobaan pembuatan papan bambu laminating, digunakan bahan pembantu berupa aluminum foil agar produk papan yang dihasilkan dapat dengan mudah dikeluarkan dari ruang alat pemanasan. Setelah prosedur persiapan pembuatan papan laminating tulangan bambu diselesaikan maka alat pemanas dipanaskan dengan gas LPG selama
2. Alat

Alat cetak papan laminating sederhana yang didesain dan dibuat oleh Tim Peneliti Baristand Industri Manado (Tipe 1), termometer, kompor LPG, alat pengujian laboratorium.

\section{HASIL PENELITIAN DAN PEMBAHASAN}

1. Perekayasaan alat pembuatan papan

laminating

Alat dibuat dari bahan besi plat dengan ketebalan $3 \mathrm{~mm}$ dan besi siku 4 $\mathrm{cm}$. Peleburan limbah plastik dilakukan secara transfer panas yang berasal dari kompor gas LPG. Alat dilengkapi dengan termometer dengan skala sampai dengan $250{ }^{\circ} \mathrm{C}$. Foto dari alat yang direkayasa adalah seperti pada Gambar 3. sekitar 60 menit, dan setelah selesai dibiarkan mendingin sekitar 30 menit. Setelah itu, papan bambu laminating dikeluarkan dari ruang pemanasan.

2. Hasil percobaan pembuatan papan laminating

Hasil percobaan pembuatan papan tulangan bambu laminating adalah seperti pada Tabel 2. 
Tabel 2. Hasil percobaan pembuatan papan tulangan bambu laminating menggunakan limbah plastik sebagai matriks

\begin{tabular}{|c|c|c|c|c|c|}
\hline No & $\begin{array}{l}\text { Tulangan } \\
\text { bambu }\end{array}$ & $\begin{array}{l}\text { Kuantitas } \\
\text { limbah } \\
\text { plastik }\end{array}$ & $\begin{array}{l}\text { Suhu } \\
\text { pemanasan }\end{array}$ & $\begin{array}{l}\text { Produk yang } \\
\text { dihasilkan }\end{array}$ & Ket \\
\hline 1 & Tiga lapis & $\begin{array}{l}\text { Limbah plastik PET berwarna } \pm 200 \mathrm{gr} \\
\text { (bekas kemasan minuman } \\
\text { berwarna biru) }\end{array}$ & $130^{\circ} \mathrm{C}$ & $\begin{array}{l}\text { Tidak } \\
\text { jadi/rapuh }\end{array}$ & - \\
\hline 2 & Tiga lapis & $\begin{array}{l}\text { Limbah plastik PET bening } \pm 200 \mathrm{gr} \\
\text { (bekas botol AMDK) }\end{array}$ & $130^{\circ} \mathrm{C}$ & $\begin{array}{l}\text { Tidak } \\
\text { jadi/rapuh }\end{array}$ & \\
\hline 3 & Tiga lapis & $\begin{array}{l}\text { Limbah plastik PP (bekas } \pm 200 \mathrm{gr} \\
\text { gelas AMDK bening berawan) }\end{array}$ & $130^{\circ} \mathrm{C}$ & $\begin{array}{l}\text { Jadi (kompak } \\
\text { dan keras) }\end{array}$ & \\
\hline 4 & Tiga lapis & $\begin{array}{l}\text { Limbah plastik PP (bekas } \pm 200 \mathrm{gr} \\
\text { penutup botol AMDK dan } \\
\text { minuman lainnya) }\end{array}$ & 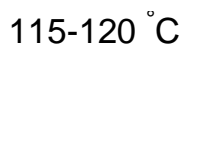 & $\begin{array}{l}\text { Jadi (kompak } \\
\text { dan keras) }\end{array}$ & \\
\hline
\end{tabular}

Hasil penelitian sebagaimana dicantumkan pada Tabel 1 menunjukkan bahwa papan laminating tulangan bambu dapat dihasilkan dengan baik (kompak dan keras) menggunakan limbah plastik jenis PP (polipropilen) bekas gelas AMDK
(Perlakuan 3) dan limbah plastik jenis PP bekas tutup botol berwarna (merah, putih, kuning, hijau, biru). Foto-foto produk papan laminating tulangan bambu limbah plastik adalah seperti pada Gambar 4 sebagai berikut. 

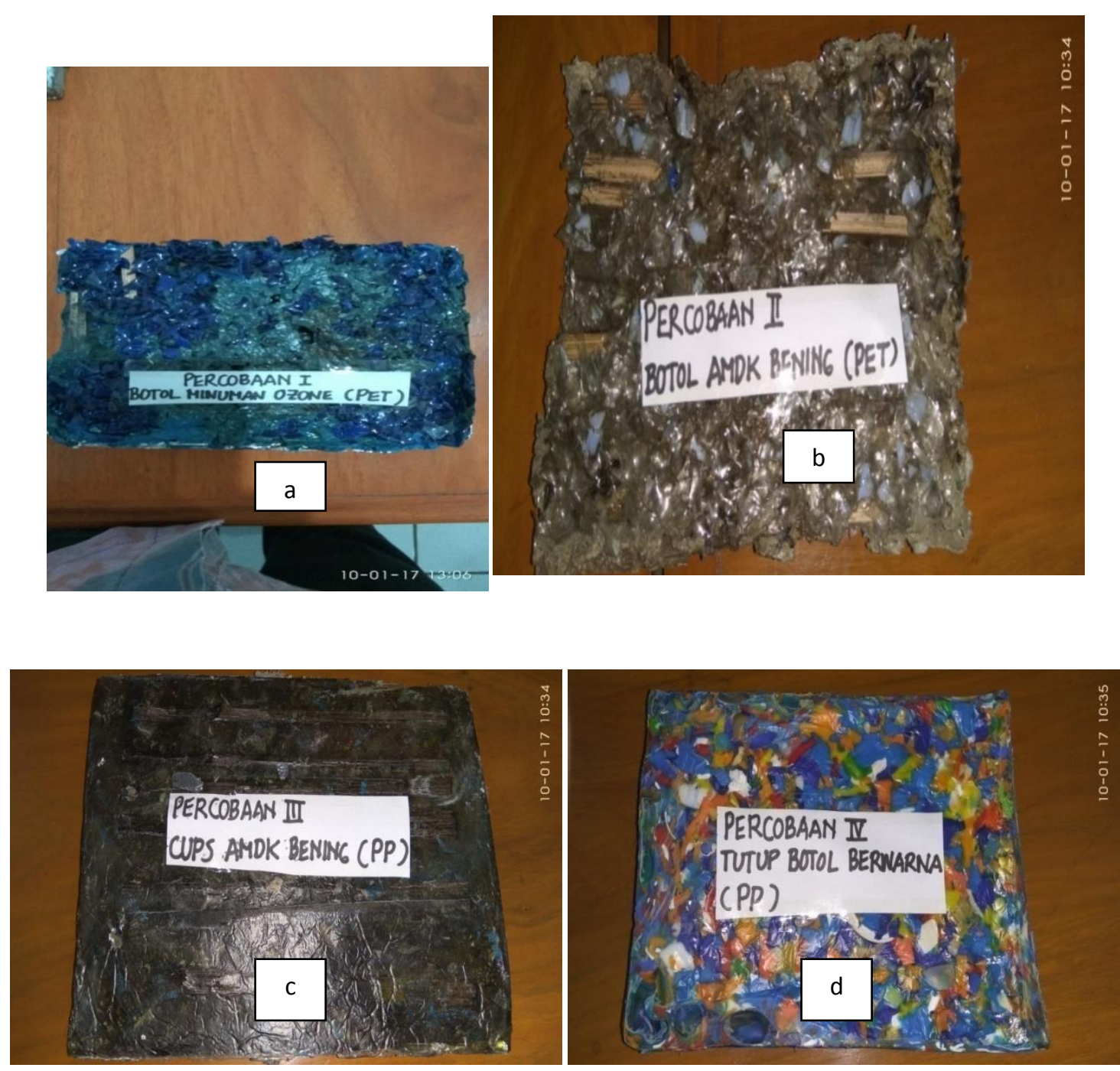

Gambar 4. Foto-foto produk papan laminating tulangan bambu dengan limbah plastik

Hasil percobaan yang telah dilakukan menunjukkan bahwa proses pemanasan perlu dilakukan secara perlahan-lahan selama sekitar 60 menit. Alat sederhana yang dirancang menunjukkan kinerja yang cukup baik sehingga dapat mendukung pencapaian tujuan penelitian. Produk yang dapat dihasilkan memiliki dimensi $20 \times 14$ $\mathrm{cm}(\mathrm{pxl})$ dengan ketebalan 1-2 cm.

Perlakuan 1 dan 2 tidak dapat menghasilkan produk papan laminating tulangan bambu, seperti yang ditunjukkan oleh Gambar 4 (a) dan (b), dimana produk kedua perlakuan tersebut tidak kompak serta rapuh/mudah hancur.

Perlakuan 3 dan 4 menghasilkan produk yang jadi dengan baik dengan kondisi benda coba yang kompak dan keras. Kekompakkan produk dapat dilihat pada Gambar 4 (c) dan (d). Tingkat kekompakkan dan kekerasan produk sangat tinggi, antara lain ditunjukkan oleh keharusan menggunakan mesin gurinda listrik untuk merapikan sisi-sisi luar dari papan laminating tersebut. 
Salah satu kendala yang ditemui pada saat pembuatan papan laminating bambu dan limbah plastik yang menggunakan tiga lapis tulangan bambu yang disusun secara bersilangan adalah dihasilkannnya produk yang cenderung bergelombang. Oleh karena itu, percobaan pembuatan papan laminating selanjutnya dilakukan menggunakan limbah plastik PP (seperti percobaan ke-3 dan ke-4) dan menggunakan tulangan bambu satu lapis dengan ukuran tulangan $18,5 \times 1 \times 1 \mathrm{~cm}$ (px|xt) yang disusun secara sejajar. Jumlah tulangan bambu yang digunakan adalah sebanyak 5 buah. Produk yang dihasilkan adalah seperti pada Gambar 5.
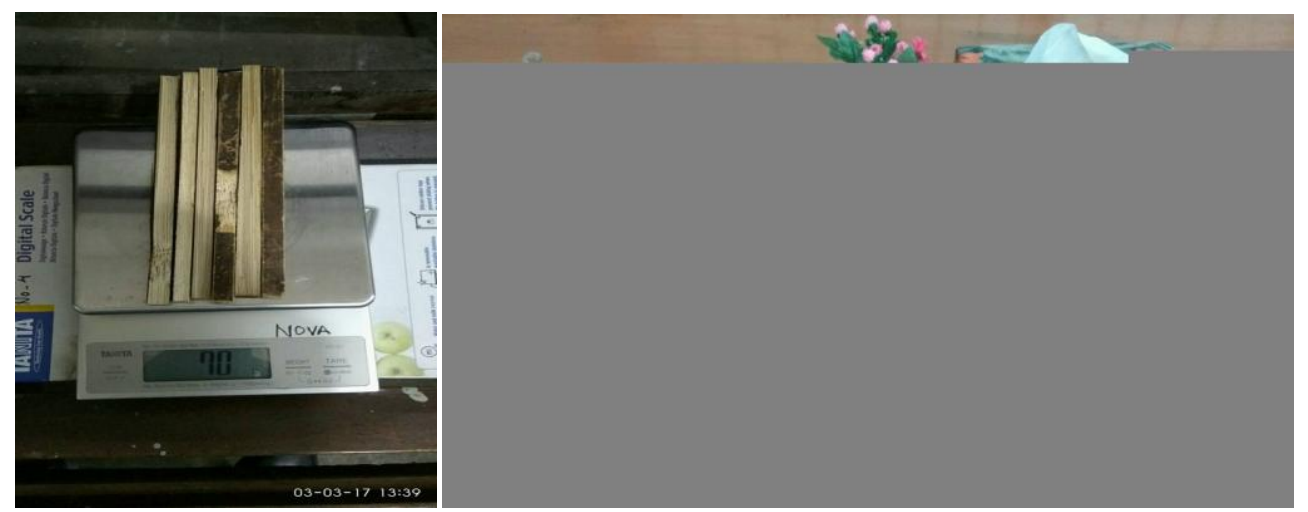

Gambar 5. Benda coba papan laminating bambu dan limbah plastik PP

Benda coba kuat lentur papan

laminating adalah seperti pada Gambar 6 tersebut di bawah.
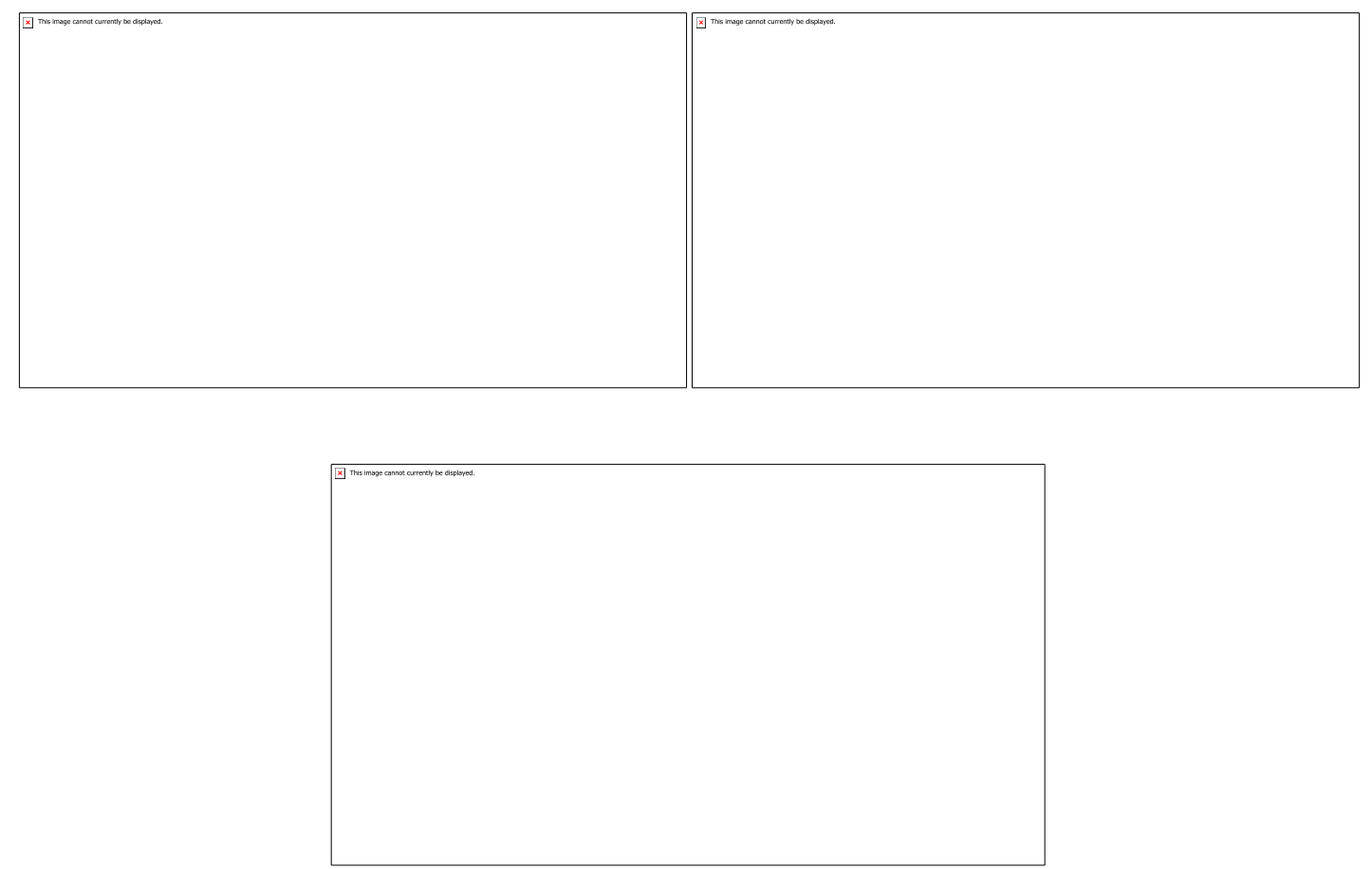

Gambar 6. Papan laminating dari bambu yang selesai diuji kuat lentur 
Kuat lentur dari produk yang

adalah seperti pada Tabel 3.

diperoleh dari hasil percobaan tersebut

Tabel 3. Pengujian kuat lentur papan laminating bambu dan limbah plastik PP (bambu satu lapis).

$\begin{array}{lccc}\text { Jenis plastik } & \begin{array}{c}\text { Percobaan } \\ \text { ke- }\end{array} & \begin{array}{c}\text { Benda coba pengujian } \\ \text { Dimensi (p,l,t } \\ \text { dalam mm) } \\ 160 \times 42 \times 11\end{array} & \begin{array}{c}\text { Berat } \\ \text { (gr) }\end{array} \\ & 1 & 160 \times 43 \times 11 & 86 \\ & & 160 \times 41 \times 11 & 92 \\ \text { PP tutup botol } & 2 & 160 \times 45 \times 11 & 102 \\ \text { AMDK } & & 160 \times 43 \times 13 & 115 \\ & 3 & 160 \times 46 \times 12 & 116 \\ & & 160 \times 48 \times 15 & 98 \\ & 1 & 160 \times 44 \times 15 & 91 \\ \text { PP cups/botol } & 2 & 160 \times 43 \times 9 & 72 \\ \text { AMDK bening } & & 160 \times 44 \times 11 & 73 \\ & & 160 \times 42 \times 15 & 85 \\ & 3 & 160 \times 42 \times 13 & 85\end{array}$

Hasil pengujian terhadap kuat lentur dari produk papan laminating menggunakan tulangan bambu satu lapis dan limbah plastik tutup botol AMDK berkisar antara 67,30-84,35 MPa (686,46$860,37 \mathrm{~kg} / \mathrm{cm}^{2}$ ), sedangkan yang menggunakan bahan limbah plastik PP cups/botol AMDK bening berkisar antara 40,14-45,59 MPa $\left(409,43-465,02 \mathrm{~kg} / \mathrm{cm}^{2}\right)$. Kisaran yang jauh dari kuat lentur pada papan laminating menggunakan plastik tutup botol AMDK kemungkinan disebabkan oleh perbedaan kekuatan tulangan bambu dan ukuran tulangan yang digunakan. Namun demikian, data yang diperoleh menunjukkan bahwa bahan dari tutup botol AMDK secara rata-rata menghasilkan produk dengan kuat lentur yang jauh lebih tinggi dibandingkan dengan yang

$\begin{array}{ccc}\begin{array}{c}\text { Pembacaan } \\ \left(\mathbf{N} / \mathbf{m m}^{2}\right)\end{array} & \begin{array}{c}\text { Kuat lentur } \\ \text { Kuat lentur } \\ (\mathbf{M P a})\end{array} & \begin{array}{c}\text { Rata-rata kuat } \\ \text { lentur }\end{array} \\ 1250 & 75,56 & \begin{array}{c}67,30 \mathrm{MPa} \\ \left(686,46 \mathrm{~kg} / \mathrm{cm}^{2}\right)\end{array} \\ 1550 & 59,03 & 73,86 \mathrm{MPa} \\ 1650 & 72,73 & \left(753,37 \mathrm{~kg} / \mathrm{cm}^{2}\right) \\ 2420 & 79,92 & 84,35 \mathrm{MPa} \\ 2450 & 88,77 & \left(860,37 \mathrm{~kg} / \mathrm{cm}^{2}\right) \\ 1750 & 38,89 & 41,87 \mathrm{MPa} \\ 1850 & 44,85 & \left(427,07 \mathrm{~kg} / \mathrm{cm}^{2}\right) \\ 800 & 55,12 & 45,59 \mathrm{MPa} \\ 800 & 36,06 & \left(465,02 \mathrm{~kg} / \mathrm{cm}^{2}\right) \\ 1470 & 37,33 & 40,14 \mathrm{MPa} \\ 1270 & 42,94 & \left(409,43 \mathrm{~kg} / \mathrm{cm}^{2}\right)\end{array}$

menggunakan limbah plastik cups/botol AMDK.

Dibandingkan dengan hasil penelitian yang dilakukan oleh Abidin, yang menghasilkan produk bambu laminating dengan menggunakan bambu susunan bilah segaris dan bahan perekat menghasilkan produk dengan kuat tekan antara $1.357,34-1580,41 \mathrm{~kg} / \mathrm{cm}^{2}(12)$, lebih tinggi dibandingkan dengan bambu laminating yang dibuat dengan limbah plastik PP. Hal ini terjadi karena volume tulangan bambu yang digunakan berbeda dimana hasil penelitian bambu laminating dengan limbah plastik hanya menggunakan tulangan bambu sebanyak $40 \%$ dibandingkan yang digunakan pada penelitian oleh Abidin. 
Dibandingkan dengan kelas Kekuatan Kayu sebagaimana tercantum pada SNI 03-3527-1994 tentang Mutu Kayu Bangunan(13), baik produk papan laminating bambu dengan limbah plastik tutup botol PP maupun cups/botol AMDK termasuk pada Kelas Kuat III (Kuat lentur patah antara $\left.437-795 \mathrm{~kg} / \mathrm{cm}^{2}\right)$.

\section{KESIMPULAN DAN SARAN}

\section{Kesimpulan}

Limbah plastik PP bekas wadah AMDK $200 \mathrm{ml}$ dan tutup botol berwarna AMDK dapat digunakan sebagai bahan matriks/perekat pada pembuatan papan laminating tulangan bambu.

Kuat lentur dari benda coba papan bambu laminating yang menggunakan limbah plastik tutup botol AMDK berkisar antara 67,30-84,35 MPa, sedangkan yang menggunakan limbah plastik cups/botol AMDK berkisar antara 40,14-45,59 MPa.

\section{Saran}

Dalam rangka menghasilkan produk yang dapat digunakan secara langsung sebagai alternatif pengganti papan (misalnya sebagai alternatif pengganti papan lumber series pada rumah panggung Tomohon) maka perlu dirancang alat pemanasan yang sesuai. Hal-hal yang perlu menjadi fokus kajian di dalam pembuatan alat adalah pada kemampuan alat untuk dapat dioperasikan dengan efektif, efisiensi energi, distribusi panas secara merata, kemudahan pengeluaran produk papan bambu laminating dari ruang pemanasan, akurasi ukuran produk (ketebalan dan dimensi), dan kualitas produk secara visual.

\section{DAFTAR PUSTAKA}

1. Widjaya EA dan RisyadZ.Anatomical properties of some bamboos utilized in indonesia national biological institute. Faculty of Forestry, Bogor Agricultural University. Bogor: International Bamboo Workshop; 1985.

2. Sonjaya J. Jenis-jenis bambu yang bernilai ekonomi. diakses dari: https://bamboeindonesia.wordpress.com/je nis/artikel-bambu/ja-sonjaya/.tanggal akses: 2015 Feb 25.

3. Liese W. Anatomy and properties of bamboo. 1980.

4. Tamalong et al. Anatomy and properties of bamboo. editorLiese W. Hamburg: Institute of Wood Biology and Wood Preservation of the Federal Research Centre for Forestry and Forest Products, Leuschnerstr, 91, 2050 Hamburg, Federal Republic of Germany; 1985.

5. Janssen JJA. The Mechanical properties of bamboo. China: International Bamboo Workshop; 1985.

6. Guisheng C.A new product of structural material with high strength properties. China:Bamboo Plywood - Nanjing;

7. XiaoYB, Shan, RZ' Yang Z, Li JC. Glue laminated bamboo (glubam) for structural applications materials and joints in timber structures. RILEM Bookseries. 2014. p. 589-601.

8. Sudin R, Narayan SN. Bamboo and wood fibre cement composites for sustainable infrastructure regeneration. J Mater Sci. ISSN: 0022.

9. Purwito. Produk dari bambu dan turunannnya.diakses dari: file:///D:/TA 2015/Litbang DIPA/Referensi/Makalah Bambu Indonesia.html.

10. Suhasman, Muhamad YM, Yusuf SHAS. Karakteristik papan partikel dari bambu tanpa menggunakan perekat. J IImu dan Teknol Has Hutan. 2010;3(1):38-43.

11. Farid Mulana, Hisbullah Hisbullah II. Pembuatan papan komposit dari plastik daur ulang dan serbuk kayu serta jerami sebagai filler. J Rekayasa Kim dan Lingkung. 2011;8(1).

12. Mohamad A. Perbedaan kuat lentur papan 
laminating bambu petung susunan bergaris dengan susunan bersilang. Fak. Teknik UM; 2013.
13. SNI 03-3527-1994 tentang Mutu Kayu Bangunan. Jakarta; 1994. 